Article

\title{
Environmental Sustainability of Building Retrofit through Vertical Greening Systems: A Life-Cycle Approach
}

\author{
Katia Perini ${ }^{1}{ }^{\oplus}$, Fabio Magrassi $^{2}{ }^{\circledR}$, Andrea Giachetta ${ }^{1}$, Luca Moreschi $^{3}$, Michela Gallo ${ }^{3}$ and Adriana Del Borghi ${ }^{3, *(1)}$ \\ 1 Architecture and Design Department, University of Genoa, 16123 Genova, Italy; katia.perini@unige.it (K.P.); \\ andrea.giachetta@unige.it (A.G.) \\ 2 Stam S.r.l., 16129 Genova, Italy; f.magrassi@stamtech.com \\ 3 Department of Civil, Chemical and Environmental Engineering, University of Genoa, 16145 Genova, Italy; \\ luca.moreschi@edu.unige.it (L.M.); michela.gallo@unige.it (M.G.) \\ * Correspondence: adriana.delborghi@unige.it
}

Citation: Perini, K.; Magrassi, F.; Giachetta, A.; Moreschi, L.; Gallo, M.; Del Borghi, A. Environmental Sustainability of Building Retrofit through Vertical Greening Systems: A Life-Cycle Approach. Sustainability 2021, 13, 4886. https://doi.org/ $10.3390 /$ su13094886

Academic Editor: Antonio Caggiano

Received: 4 March 2021

Accepted: 22 April 2021

Published: 27 April 2021

Publisher's Note: MDPI stays neutral with regard to jurisdictional claims in published maps and institutional affiliations.

Copyright: (C) 2021 by the authors Licensee MDPI, Basel, Switzerland. This article is an open access article distributed under the terms and conditions of the Creative Commons Attribution (CC BY) license (https:/ / creativecommons.org/licenses/by/ $4.0 /)$.

\begin{abstract}
Urban greening provides a wide range of ecosystem services to address the main challenges of urban areas, e.g., carbon sequestration, evapotranspiration and shade, thermal insulation, and pollution control. This study evaluates the environmental sustainability of a vertical greening system (VGS) built in 2014 in Italy, for which extensive monitoring activities were implemented. The life-cycle assessment methodology was applied to quantify the water-energy-climate nexus of the VGS for $1 \mathrm{~m}^{2}$ of the building's wall surface. Six different scenarios were modelled according to three different end-of-life scenarios and two different useful lifetime scenarios (10 and 25 years). The environmental impact of global-warming potential and generated energy consumption during the use phase in the VGS scenarios were reduced by $56 \%$ in relation to the baseline scenario (wall without VGS), and showed improved environmental performance throughout the complete life cycle. However, the water-scarcity index (WSI) of the VGS scenarios increased by $42 \%$. This study confirms that the installation of VGSs offers a relevant environmental benefit in terms of greenhouse-gas emissions and energy consumption; however, increased water consumption in the use phase may limit the large-scale application of VGSs.
\end{abstract}

Keywords: vertical greening systems; life-cycle assessment; building retrofitting; water-energyclimate nexus

\section{Introduction}

Urban greening provides a wide range of ecosystem services to address the main challenges of urban areas, e.g., carbon sequestration to fight climate change; evapotranspiration and shade for urban climate; insulation, shelter, and shade for energy management and pollution control for wellbeing and health; and aesthetics for amenity value [1]. In particular, the retrofitting field plays a fundamental role in giving cities more green areas to improve environmental conditions [2] and to contribute towards European primary energy-consumption reduction goals [3].

Many vegetation characteristics can be exploited to retrofit: recently built heritage sites with uninsulated building envelopes that lack thermal mass and heritage buildings with the lowest architectural value, free of cultural and historical limits, are examples of possible applications of building retrofitting through greening systems [4].

Due to the lack of space in dense urban centers, greening building envelopes represent an opportunity to restore the environmental conditions of cities [5]. However, attention should be paid to the environmental impact of each system, since building construction and use consume a significant amount of energy and water [6-9]. Vertical greening systems (VGSs) can be classified into green façades and living walls according to the employed growing method and supporting structure, and entail different environmental costs besides aesthetics characteristics [10-14]. VGS characteristics and plant species also influence their 
performance: improved energy performance in buildings [15,16], fine-dust-collecting capacity [17], and biodiversity improvement [18,19]. Life-cycle assessment (LCA), a methodology regulated by the ISO 14040:2006 [20], is a useful tool for measuring the environmental sustainability of a building component. LCA can be used to measure if the benefits balance the environmental burden, considering the environmental costs of production, transport, use, maintenance, and disposal of all components [21].

According to several studies [13,22-24], material selection highly influences the environmental burden of VGSs. Manso et al. [22] showed that the use of recycled materials or industrial waste can lower the environmental impact.

Other important aspects include the maintenance phase: pruning, replacement of dead plants or ruined panels, irrigation needs, and wastewater treatment $[13,14,25,26]$.

Ottelé et al. [13] noted in an LCA of four vertical greening systems attached to a double brick wall with insulation material (a direct green façade, an indirect one, a livingwall system based on HDPE planter boxes, and one based on felt layers) energy savings as an environmental benefit, using simulation data and other studies' data. The study showed that the cooling potential of the Mediterranean area is fundamental to balancing the environmental burden of living-wall systems. Direct green façades (no additional materials used) were showed to be sustainable options, while for indirect green façades, results depended on the used materials. The study also showed that the felt layer system can have a high environmental burden, mainly due to durability aspects. Feng and Hewage [27] analyzed the same systems, and compared air cleaning and energy saving (operation phase) with material production, construction, maintenance, and disposal stages, reaching similar conclusions. Pan and Chu [23] quantified the environmental benefits and burdens of a VGS in Hong Kong, exploring the energy savings of cooling a room with an external wall covered by a VGS $\left(8.22 \mathrm{~m}^{2}\right)$ for a life span of 50 years. The $16 \%$ energy savings offset the costs of the VGS over the 50-year life span in terms of global warming. Since VGSs-as green roofs and green areas, providing important ecosystem services and improving the thermal performance of buildings - may improve the environmental conditions of cities, the present paper aims to quantify the environmental load related to their installation, maintenance, and disposal, and verify whether the environmental benefits balance these impacts. To thoroughly investigate the role of disposal phase, different end-of-life scenarios are presented. Previous research [13,27] is based on published or simulation data, or focuses on a different climate context [23]. This study evaluates the environmental sustainability of a VGS built in 2014 in Italy, on which extensive monitoring and research were conducted by the authors $[17,28-30]$, providing data to accurately estimate the environmental benefits and costs.

\section{Materials and Methods}

\subsection{Case Study}

The VGS under investigation is installed at the National Institute of Social Insurance (INPS) headquarters in Sestri Ponente, Genoa, Italy. Genoa is located on the northwestern coast of Italy, and it is characterized by a Mediterranean climate with hot dry summers and mild wet winters. The system, called the INPS Green Façade pilot project, was built in 2014 on the southern wall of an office building renovated in the 1980s (as illustrated in Figure 1). The system covers $129 \mathrm{~m}^{2}$, and steel meshes for climbing plants cover $35 \mathrm{~m}^{2}$ of the external wall, which is exposed to solar radiation for $8 \mathrm{~h} /$ day in summer and 1-2 h/day during winter. The latter constitutes two layers of masonry with a $51 \mathrm{~cm}$ air gap and a $5 \mathrm{~cm}$ insulating layer (polystyrene) placed between the air cavity and the external layer of masonry. The thermal transmittance of the external walls is $0.44 \mathrm{~W} / \mathrm{m}^{2} \mathrm{~K}$, and total thickness is $85 \mathrm{~cm}$.

The system selected for the installation is a living-wall system comprising geotextile panels planted with climbing plants and small shrubs (among which Rhincosperma jasminoide, Hedera helix, Phlomis fruticosa, and Cistus Jessamy beauty). The panels are irrigated with about $2.5 \mathrm{~L} / \mathrm{m}^{2}$ day with a drip line in each module. Starting from 2014, several 
monitoring activities were implemented to quantify the environmental, economic, and social benefits of the pilot project. A sociological investigation included before-and-after construction analysis of citizens' perception of greening systems [28,31]; the fine-dustcollecting capacity by different system plants showed that leaf characteristics influence their performance [17]. The cooling performance of the VGS was quantified using field measurements $[29,32]$. Obtained data were used to evaluate the economic sustainability of the INPS Green Façade pilot project [30]. Economic analysis showed that a VGS can be economically sustainable when tax reduction on installation costs is considered; in this case, the net present value and the internal rate of return are positive, and the payback period is lower than the lifespan of VGS is. Another relevant benefit is energy savings on summer conditioning in buildings due to reduced external air temperature. Sensitivity analysis on the main variables underlined the relevance of the design phase with optimizing the choice of materials and technological solutions, reducing installation and maintenance costs. Therefore, the present research represents the last element to complete the picture (as illustrated in Figure 2).

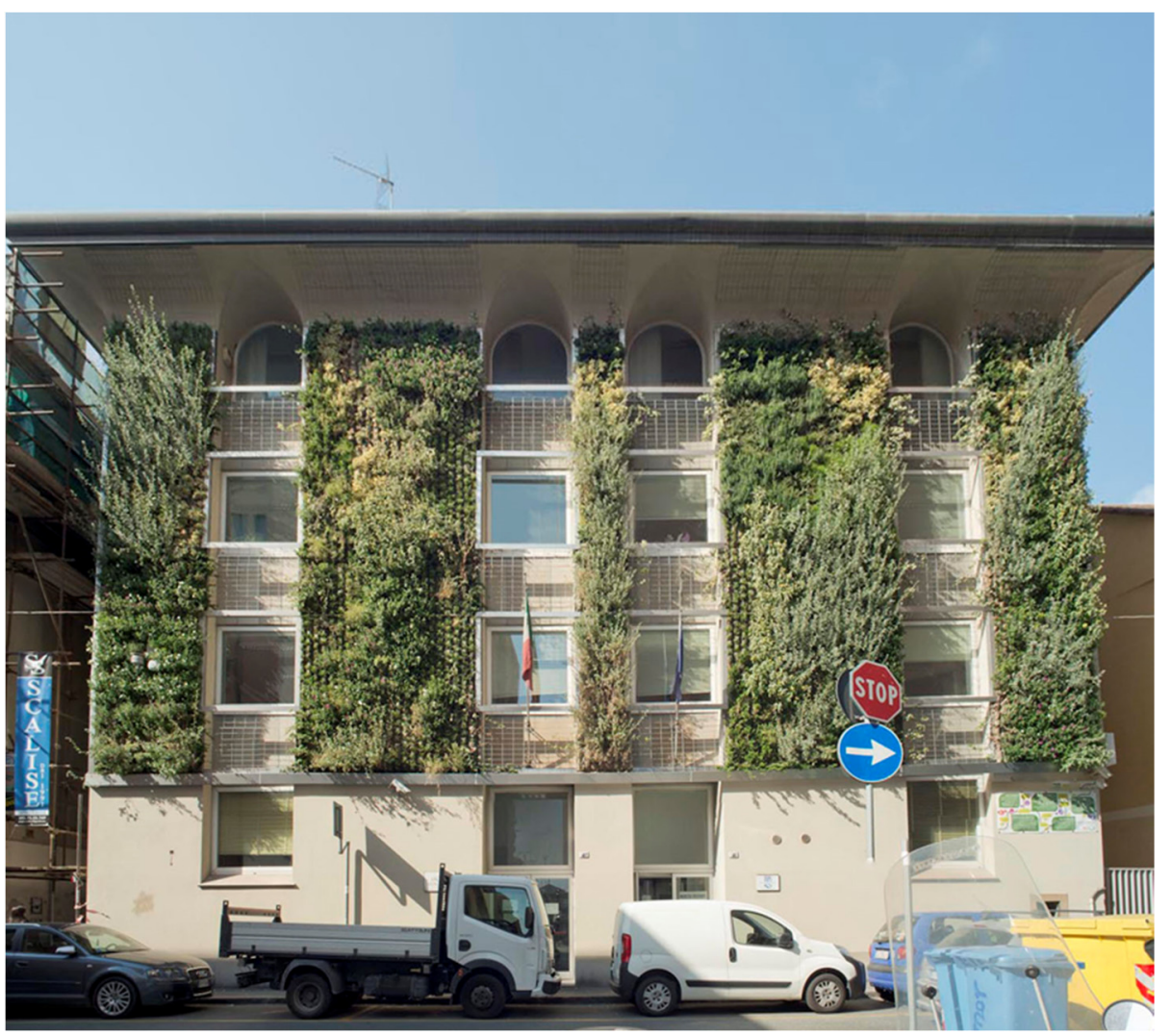

Figure 1. Pilot project National Institute of Social Insurance (INPS) Green Façade, Genoa, Italy.

\subsection{Methods and Data}

LCA, a standardized environmental management tool for estimating the effects of a product's system on the environment over the entire period of its life [33], was implemented to evaluate the potential environmental impacts associated with the INPS Green Façade pilot project. Results were then compared to the scenario without a VGS.

A comparative LCA approach is an effective tool for evaluating resource efficiency in cleaner production alternatives.

The basis for comparison is represented by the functional unit, here defined as $1 \mathrm{~m}^{2}$ of building wall surface.

To provide a clear picture of the potential effects of a VGS, a cradle-to-grave approach was chosen for drawing the system boundaries (as illustrated in Figure 3). The cultivation 
of vegetation used for the VGS is included in the cutoff, as the cultivation of plants has limited impact compared to the materials and energy consumed throughout the building life cycle. A life span of 10 and 25 years and different end-of-life scenarios, depending on the percentages of solid-waste disposal, recycling, and biomass production, were analyzed. Ten years represent the guaranteed lifetime according to the manufacturer's product specifications, so we assumed a maximal durability of 25 years for the VGS under analysis. Although other studies $[13,27]$ considered longer time frames, according to the company responsible for the VGS installation, issues could arise after 25 years.

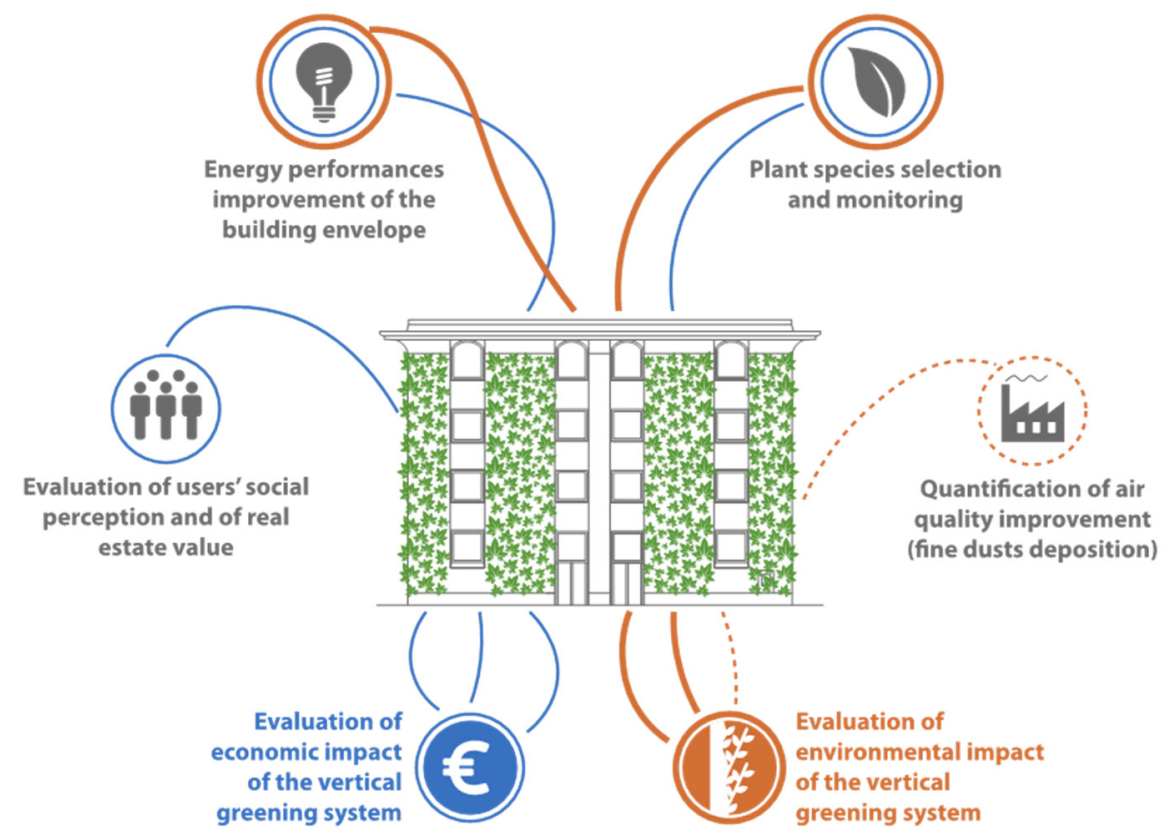

Figure 2. Scheme of monitoring activities developed since 2014.

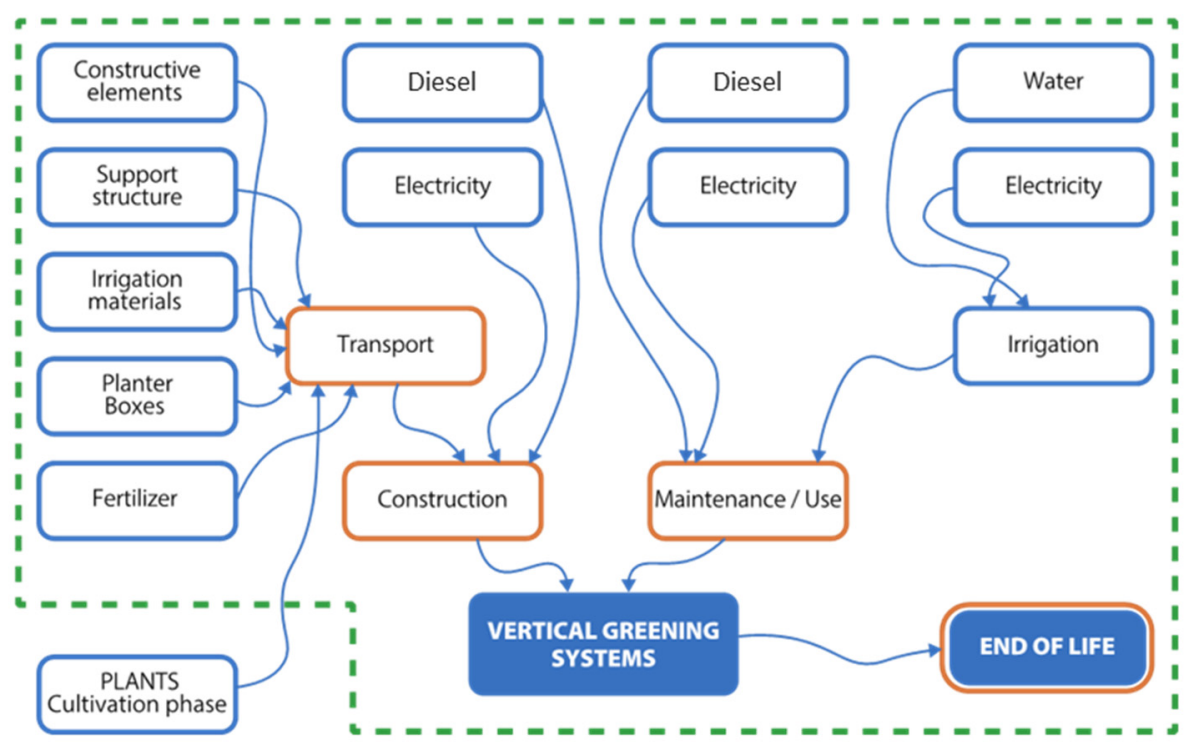

Figure 3. System boundaries under investigation.

\subsubsection{Life-Cycle Inventory}

Among the wide range of ecosystem services provided by a VGS, some are difficult to quantify or analyze from a life-cycle perspective. Air-quality improvement [17] is considered to be an additional benefit. In this study, cooling potential and related energy-saving 
data were retrieved from previously published research by the authors. Perini et al. [29] performed an experimental investigation to evaluate the cooling potential of the INPS Green Façade during summer (1 June to 30 September) through a monitoring campaign that lasted three years (2015-2017; in 2017, the month of September was excluded). To exploit the cooling capacities of the green layer, an $8 \mathrm{~cm}$ diameter duct was implemented throughout the building wall behind the VGS, connecting the internal surface with the external surface (as illustrated in Figure 4). An impeller placed inside the ducts (axial fan AC $80 \times 80 \times 25 \mathrm{~mm}$, max air flow $41 \mathrm{~m}^{3} \mathrm{~h}^{-1}$ ) extracted air from outside and supplied it to the room. Air-temperature data recorded by a resistance-temperature detector were compared with the data recorded in a second duct placed $4 \mathrm{~m}$ below, which extracted air from outside without the influence of greening [29]. Therefore, the cooling capacities of vertical greening systems were evaluated by comparing green and nongreen solutions without the influence of internal conditions (e.g., air conditioning, heating, and internal loads). For energy-saving calculation, the period of the day corresponding to office building occupancy was considered, i.e., from 8 a.m. to 6 p.m.

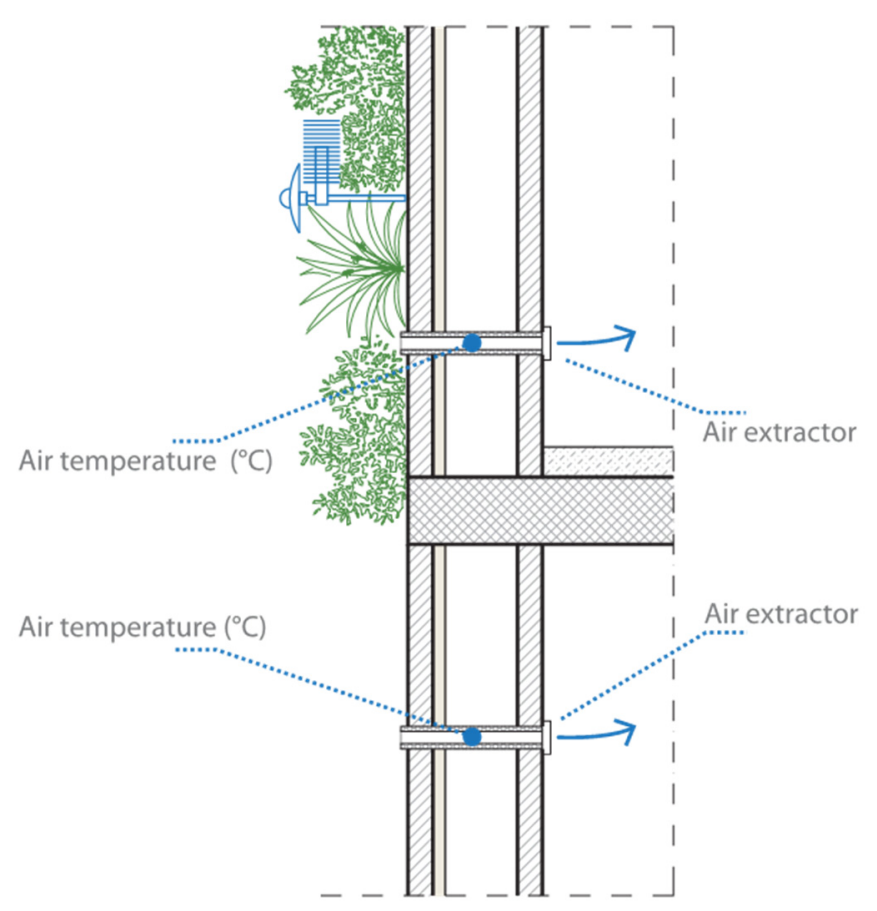

Figure 4. Cross-sectional detail of façade showing ducts for air-temperature monitoring.

Recorded air-temperature data were used to calculate the energy saving for air conditioning [30], assuming that a device for extracting air from the ducts was provided for each room. The cooling demand of the two rooms (the one corresponding to the greening system and the one below) was calculated with Edilclima software [34], according to Italian regulation UNI-TS 11300 part 3, and was consistent with the requirements of current Directive 2010/31/EU [35]. Data reported in Table 1 show monthly average temperature differences between green and no-green in the range of $1.5-6{ }^{\circ} \mathrm{C}$, resulting in a total delta kWh of 7792 in 2015, 3616 in 2016, and 3903 in 2017.

All data related to constructive elements, supporting structure, irrigation material, planter boxes, and fertilizer were provided by the company in charge of the construction. This company carried out all maintenance work from 2014 to 2018 and provided the required data for the maintenance or use phase. Maintenance includes twice-per-year pruning performed using an elevated platform operating for $8 \mathrm{~h}$. During this time frame, dead or sick plant species were replaced (in total, 10\% for the first year and $3 \%$ for the following years). Other data concerning the regular operation and maintenance of the building were excluded, as they were considered equal in both the VGS and non-VGS 
scenarios. This approach is methodologically acceptable owing to the comparative nature of the LCA study. Collected data are summarized in Table 2.

Table 1. Energy demand of building with and without a VGS from 8 a.m. to 6 p.m.

\begin{tabular}{|c|c|c|c|c|c|}
\hline Month & $\begin{array}{l}\text { Air Extracted } \\
\text { from Outside }\end{array}$ & $\begin{array}{l}\text { Energy Demand } \\
\text { without Green } \\
(\mathbf{k W h})\end{array}$ & $\begin{array}{c}\text { Air Extracted } \\
\text { Behind Vertical Greening } \\
\left.\text { System (VGS; }{ }^{\circ} \mathrm{C}\right)\end{array}$ & $\begin{array}{l}\text { Energy Demand } \\
\text { with Green } \\
(\mathrm{kWh})\end{array}$ & $\begin{array}{l}\text { Delta } \\
\text { kWh } \\
(\mathrm{kWh})\end{array}$ \\
\hline \multicolumn{6}{|l|}{2015} \\
\hline June & 26.5 & 2935.0 & 21.3 & 726.0 & 2209.0 \\
\hline July & 29.8 & 4637.0 & 24.6 & 2265.0 & 2372.0 \\
\hline August & 27.3 & 3344.0 & 22.7 & 1257.0 & 2087.0 \\
\hline September & 23.0 & 1326.0 & 19.2 & 202.0 & 1124.0 \\
\hline Total 2015 & & $12,242.0$ & & 4450.0 & 7792.0 \\
\hline \multicolumn{6}{|l|}{2016} \\
\hline June & 25.6 & 2537.0 & 22.6 & 1225.0 & 1312.0 \\
\hline July & 23.8 & 1900.0 & 21.7 & 986.0 & 914.0 \\
\hline August & 21.3 & 706.0 & 18.3 & 123.0 & 583.0 \\
\hline September & 23.2 & 1412.0 & 21.1 & 605.0 & 807.0 \\
\hline Total 2016 & & 6555.0 & & 2939.0 & 3616.0 \\
\hline \multicolumn{6}{|l|}{2017} \\
\hline June & 22.2 & 1061.0 & 20.7 & 540.0 & 521.0 \\
\hline July & 25.6 & 2721.0 & 23.7 & 1855.0 & 866.0 \\
\hline August & 26.3 & 2888.0 & 20.1 & 372.0 & 2516.0 \\
\hline Total 2017 & & 6670.0 & & 2767.0 & 3903.0 \\
\hline
\end{tabular}

Table 2. Inventory data.

\begin{tabular}{|c|c|c|c|}
\hline Life-Cycle Phases & Inventor Data & Without Green & With Green \\
\hline \multirow{2}{*}{ Wall } & Surface $\left(\mathrm{m}^{2}\right)$ & & 129 \\
\hline & Plants (No. $/ \mathrm{m}^{2}$ ) & & 38 \\
\hline \multirow{8}{*}{ Construction } & Constructive elements & & \\
\hline & - $\quad$ Tracks (m/wall) & - & 433 \\
\hline & - $\quad$ Plate (pieces/wall) & - & 90 \\
\hline & - $\quad$ Corner (pieces/wall) & - & 54 \\
\hline & Support structure $\left(\mathrm{m}^{2}\right)$ & - & 129 \\
\hline & Irrigation material-PVC (m) & - & 260 \\
\hline & Planter boxes-HDPE $(\mathrm{kg})$ & - & 3.3 \\
\hline & Diesel (MJ/wall) & - & 6942 \\
\hline \multirow{9}{*}{ Maintenance/use } & Electricity for cooling (kWh/year) & 8945 & 3520 \\
\hline & Electricity for irrigation (kWh/year) & & 36.5 \\
\hline & Diesel (MJ/year) & - & 1157 \\
\hline & Fertilizer production (kg/year) & - & 12.5 \\
\hline & Fertilizers emissions to air & & \\
\hline & - $\quad \mathrm{kg} \mathrm{NH}_{3} /$ year & - & 49.5 \\
\hline & - $\quad \mathrm{kg} \mathrm{NO} /$ year & - & 47.85 \\
\hline & - $\quad \mathrm{kg} \mathrm{N}_{2} \mathrm{O} /$ year & - & 36.3 \\
\hline & Water $\left(\mathrm{m}^{3} /\right.$ year $)$ & - & 134.676 \\
\hline
\end{tabular}

The VGS disposal phase comprises the following processes: removal of the support structure, planter boxes, and plants; transport; and waste management (recycle-plastic and biomass; final disposal-landfill or incineration). Six end-of-life scenarios were modelled for a life span of either 10 or 25 years. Table 3 shows the made assumptions. End-of-life 
Scenarios 2 and 5 were modelled according to the Italian waste-management system as defined in the municipal waste report [36]. The other scenarios present hypothetical waste-management systems: Scenarios 1 and 4 consider the complete disposal or energy recovery of plastic materials and biomass; Scenarios 3 and 6 consider the full recycling of the same materials.

Table 3. End-of-life scenarios.

\begin{tabular}{|c|c|c|c|c|}
\hline \multirow{2}{*}{ Scenario } & \multirow{2}{*}{ Life Span (Years) } & \multicolumn{2}{|c|}{ Recycling } & \multirow{2}{*}{$\begin{array}{c}\text { Final Disposal and/or } \\
\text { Energy Recovery }\end{array}$} \\
\hline & & Plastic & Biomass & \\
\hline 1 & \multirow{3}{*}{10} & - & - & $100 \%$ \\
\hline 2 & & $42.1 \%$ & - & $57.9 \%$ \\
\hline 3 & & $100 \%$ & $100 \%$ & - \\
\hline 4 & \multirow{3}{*}{25} & - & - & $100 \%$ \\
\hline 5 & & $42.1 \%$ & - & $57.9 \%$ \\
\hline 6 & & $100 \%$ & $100 \%$ & - \\
\hline
\end{tabular}

\subsubsection{Impact Assessment}

The life-cycle impact assessment (LCIA) phase is performed at the midpoint level through a set of three indicators, i.e., global-warming potential (GWP), cumulative energy demand (CED), and water-scarcity index (WSI). Globally acknowledged methodologies were selected for characterizing these types of impact on climate change, energy resources, and water, respectively.

This set of impact categories, relying on possible standalone indices, was identified to pave the way for water-energy-climate nexus quantification by means of the LCA tool. Analysis of the water-energy nexus is a novel approach that is especially prominent in the food sector [37], but with a theoretical applicability to different sectors, products, and scenarios. The goal of the water-energy-climate nexus is to highlight the potential interconnections between three relevant environmental issues: the consumption of energy resources, the emission of greenhouse gases, and the availability and consumption of water resources.

Following the most acknowledged and robust patterns to demonstrate the effects of climate change, mainly related to the use of nonrenewable fuels, GWP was calculated using factors derived from the fifth IPCC report [38].

Energy use was evaluated through the CED method. This approach for energy accounting is expected to overtake analysis of cumulative fossil and renewable-energy demands [39].

Additionally, a WSI indicator was used only to address the consumption of water through a recently developed method [40].

This indicator, in line with the assessment of a "water-scarcity footprint", according to the requirements of ISO 14046:2016 [33], was built on a consumption-to-availability ratio, calculated as the fraction between consumed (otherwise referred to as blue water footprint) and available water.

\section{Results}

Environmental results are presented in Table 4 according to the different indicators and life spans selected. Analyzing the six different scenarios, the complete recycling of materials at end of life (Scenarios 3 and 6) reduced the environmental impact, but presented no relevant variations regarding other end-of-life scenarios.

As shown in Figures 5 and 6, the application of VGS allows for a reduction in GWP and CED of about 29-30\% over a 10-year lifespan and 45-46\% over a 25-year lifespan. On the other hand, the WSI indicates an increase in water consumption of $52 \%$ on a 10 -year basis and $46 \%$ over 25 years. As expected, the increase in water consumption is mainly due 
(above $90 \%$ ) to the water demands of irrigation, which causes an increase of $42 \%$ in the WSI indicator for the sole use phase.

Table 4. Environmental indicators for $1 \mathrm{~m}^{2}$ of building wall surface.

\begin{tabular}{|c|c|c|c|c|c|c|c|}
\hline \multirow[b]{2}{*}{ Scenario } & \multirow[b]{2}{*}{ Life Span (Years) } & \multicolumn{3}{|c|}{ Without Green } & \multicolumn{3}{|c|}{ With Green } \\
\hline & & $\begin{array}{c}\text { GWP } \\
\left(\mathrm{kg} \mathrm{CO} \mathrm{CO}_{2} \text { eq }\right)\end{array}$ & $\begin{array}{l}\text { CED } \\
\text { (MJ) }\end{array}$ & $\begin{array}{c}\text { WSI } \\
\left(\mathrm{m}^{3} \text { eq }\right)\end{array}$ & $\begin{array}{c}\mathrm{GWP} \\
\left(\mathrm{kg} \mathrm{CO} \mathrm{CO}_{2 \text { eq }}\right)\end{array}$ & $\begin{array}{l}\text { CED } \\
\text { (MJ) }\end{array}$ & $\begin{array}{c}\text { WSI } \\
\left(\mathrm{m}^{3} \text { eq }\right)\end{array}$ \\
\hline 1 & \multirow{3}{*}{10} & \multirow{3}{*}{316.41} & \multirow{3}{*}{5937.12} & \multirow{3}{*}{212.40} & 225.49 & 4165.56 & 322.57 \\
\hline 2 & & & & & 224.20 & 4165.91 & 322.51 \\
\hline 3 & & & & & 222.34 & 4165.46 & 322.42 \\
\hline 4 & \multirow{3}{*}{25} & \multirow{3}{*}{791.02} & \multirow{3}{*}{$14,842.80$} & \multirow{3}{*}{531.01} & 434.80 & 8008.36 & 774.29 \\
\hline 5 & & & & & 433.51 & 8008.71 & 774.23 \\
\hline 6 & & & & & 431.62 & 8007.96 & 774.14 \\
\hline
\end{tabular}

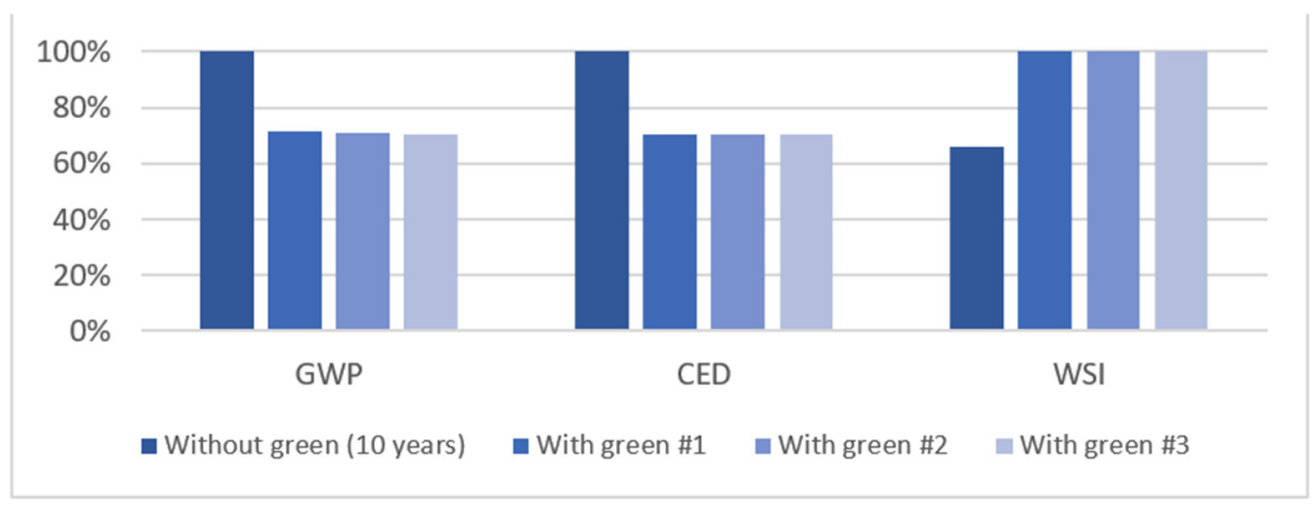

Figure 5. Comparison of environmental indicators for a lifespan of 10 years.

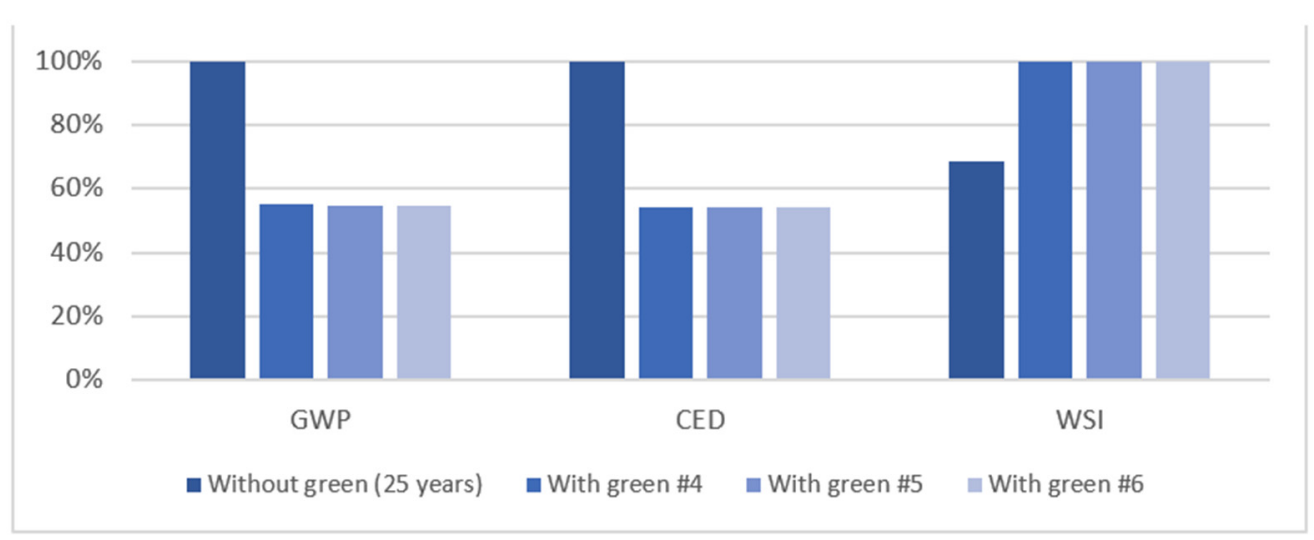

Figure 6. Comparison of environmental indicators for a lifespan of 25 years.

Analysis of the contribution of the single life-cycle phases (Figures 7-9) to the scenarios with VGS shows that the use phase contributed the most in all the selected indicators. However, the maintenance of the irrigation system and the waste management of VGS materials generate almost negligible impacts in all the categories. On the one hand, the maintenance phase represents, at most, $0.1 \%$ of the overall impact for all indicators in all scenarios. On the other hand, the end-of-life phase generates, at most, $1.65 \%$ of the overall GWP in Scenario 1, whereas its contribution does not surpass $0.1 \%$ in CED and WSI for all scenarios. 


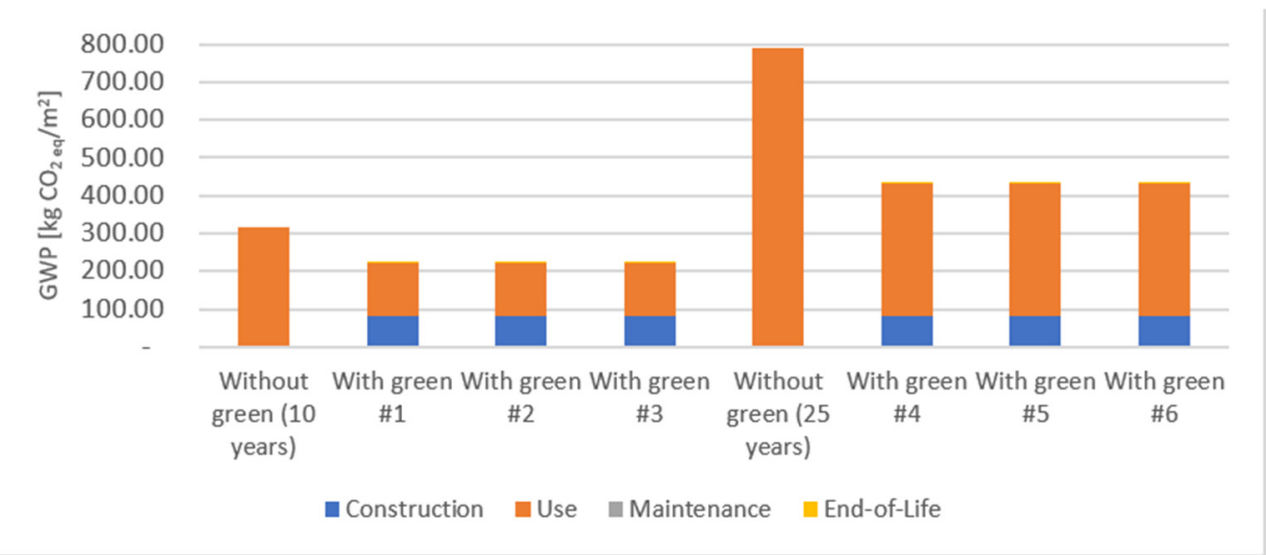

Figure 7. Global-warming-potential (GWP) indicators divided into life-cycle phases.

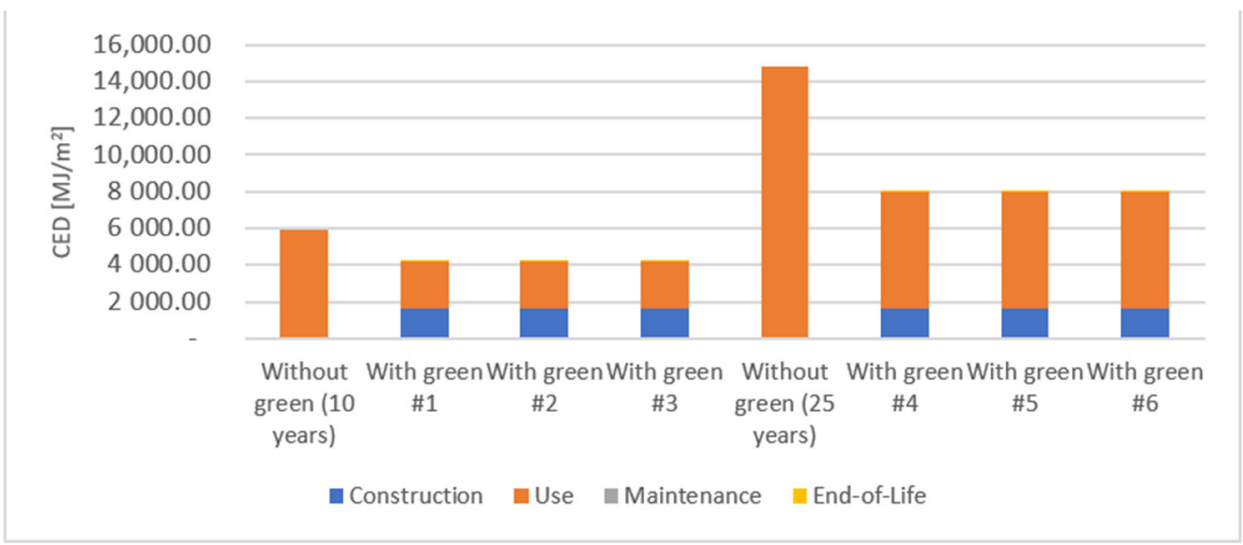

Figure 8. Cumulative-energy-demand (CED) indicators divided into life-cycle phases.

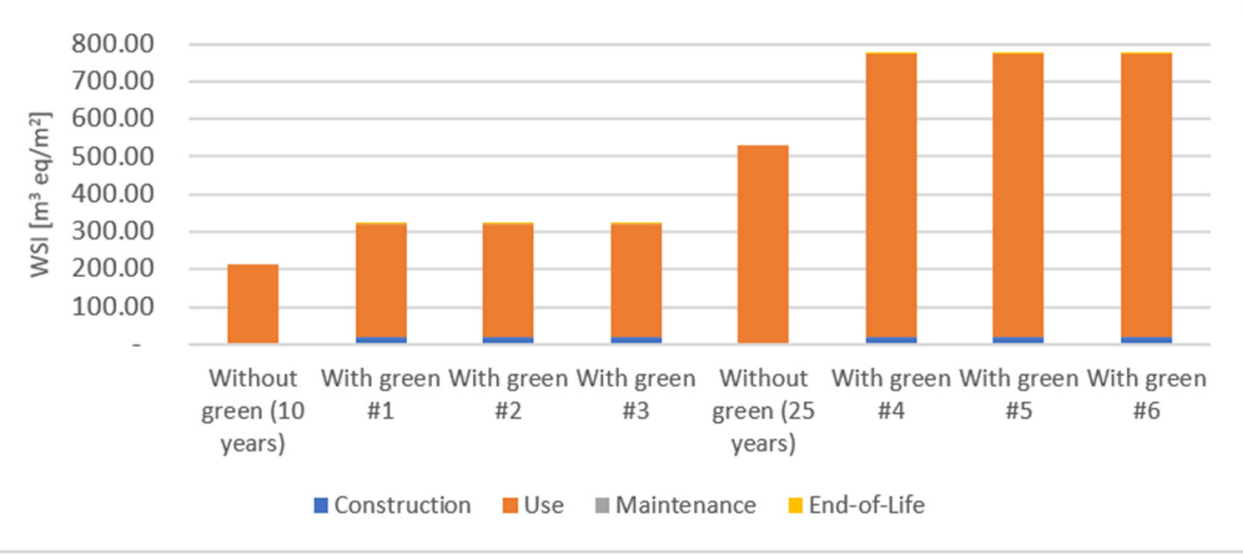

Figure 9. Water-scarcity-index (WSI) indicators divided into life-cycle phases.

Especially for a VGS lifetime of 10 years, the construction phase determines a relevant impact as far as GWP and CED are concerned, contributing almost $40 \%$ of the overall impact. On a 25-year basis, the contribution of the construction phase is still relevant, but it is reduced to about $20 \%$ of the overall impact.

The environmental impacts of GWP and CED generated during the use phase in the VGS scenarios were reduced by $56 \%$ with respect to the baseline scenario, and showed clear improvement in environmental performance. However, this improvement must be supported by the proper selection of construction materials that deliver reduced environ- 
mental impact and remain useful for their full lifespan to overcome the benefits deriving from the use phase.

Moreover, properly selecting the irrigation system could optimize water consumption in the use phase, but this cannot stop the increase in the WSI indicator for the VGS scenarios. This condition may be a limitation for the application of VGSs on a large scale, as water demand for irrigation could become unsustainable in relation to water availability for the area. Nevertheless, the application of rainwater collection or grey water-purification systems could reduce the water footprint and increase the overall environmental sustainability of VGSs on a large scale.

\section{Discussion}

The VGS under investigation was installed at the INPS headquarters in Sestri Ponente, Genoa, Italy. Primary data regarding the trends in external air temperature and energy demands for cooling in the summer seasons were collected in the years of 2015-2017.

This being comparative analysis in line with LCA methodology, all data concerning the ordinary operation and maintenance of the building were neglected, as they were considered equal for both with- and without-VGS scenarios.

All data related to constructive elements, supporting structure, irrigation material, planter boxes, and fertilizer were provided by the construction company who offered a complete inventory for proper LCA analysis throughout the whole life cycle of the VGS. The same company carried out all maintenance works from 2014 to 2018, and therefore provided the required data for the maintenance or use phase.

The results of the study confirm that the installation of VGSs offers improvement in the energy performance of buildings $[15,16]$, and this leads to a relevant environmental benefit, i.e., greenhouse-gas emissions and energy-resource consumption.

Despite common LCA labels, studies and international standards for the building sector [41] apply and /or recommend a larger set of indicators for environmental performance assessments, and this paper focused on the three indicators related to the water-energyclimate nexus, i.e., global-warming potential (GWP), cumulative energy demand (CED), and water-scarcity index (WSI). Nevertheless, as the use phase resulted in being the most impactful phase, and energy consumption represents its main contributor, energy savings offered by the installation of VGSs should reasonably guarantee similar environmental benefits to all emissions-related impact categories.

As shown in Figure 10, about 5 years after the installation of the VGS, greenhouse-gas emissions in terms of GWP equalize the emissions that would be generated according to the baseline scenario (without VGS). In this way, a "break-even" point is reached, and the VGS-implemented building starts to gain an environmental benefit. The six different scenarios differ in the expected lifetime and in the end-of-life of the VGS, but as the endof-life phase slightly affects the overall impact, the trendlines overlap. Figures 11 and 12 highlight the variations in the trendlines at the end-of-life stage: at Year 10 for Scenarios 1 to 3 , and at Year 25 for Scenarios 4 to 6.

Similar results were obtained regarding CED. The temporal shifting of the break-even point is both influenced by VGS performance during the use phase, and by the overall impact of the construction phase. The greater the impact of the construction phase is, the more the break-even point is postponed. Thus, the importance of a proper selection of construction materials that are able to deliver reduced environmental impact and a lasting, useful life was confirmed [13,22-24]. A break-even point can be reached even in shorter periods if building energy-efficiency measures are coupled with the application of sustainable energy-production systems [42,43].

Cost/benefit analysis also underlined the relevance of the design phase and material selection, and further investigations into these aspects could help to better understand the extent and variability of both the environmental and economic benefits related to VGS installation.

Despite the considerable advantages offered by VGSs, increased water consumption in the use phase may result in being a limiting factor for the application of VGSs on a 
large scale, as water demand for irrigation could become unsustainable with respect to water availability for an area. Future studies should focus on the application of rainwater collection or grey water-purification systems, and on the selection of optimal plant species to reduce the water footprint and increase the overall environmental sustainability of VGSs.

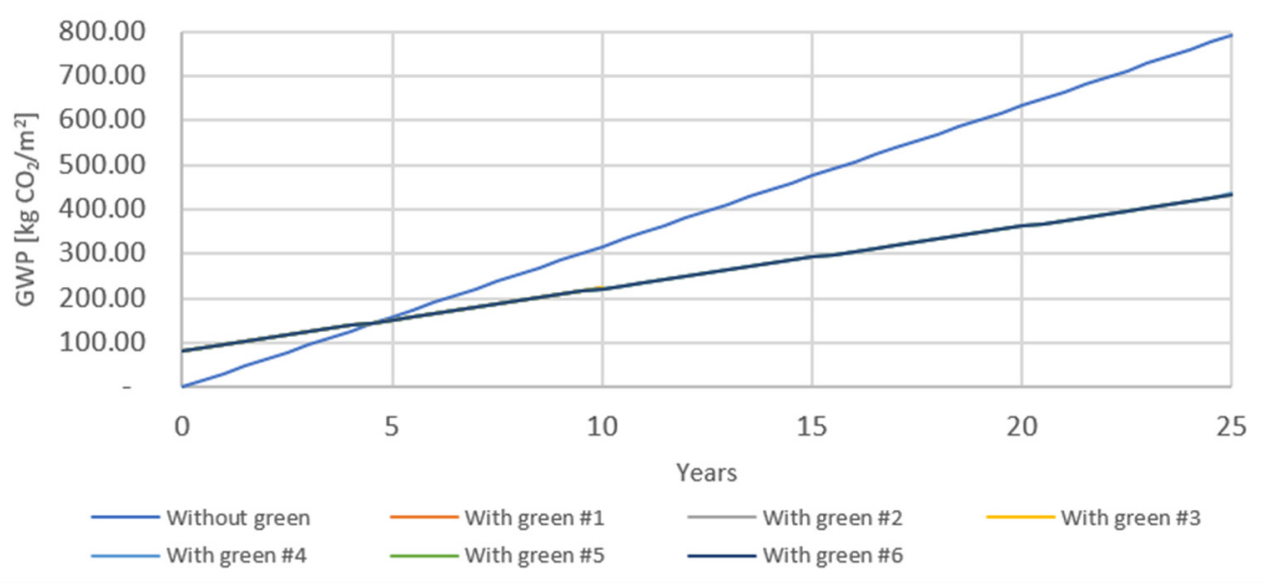

Figure 10. GWP trendlines throughout VGS lifetime.

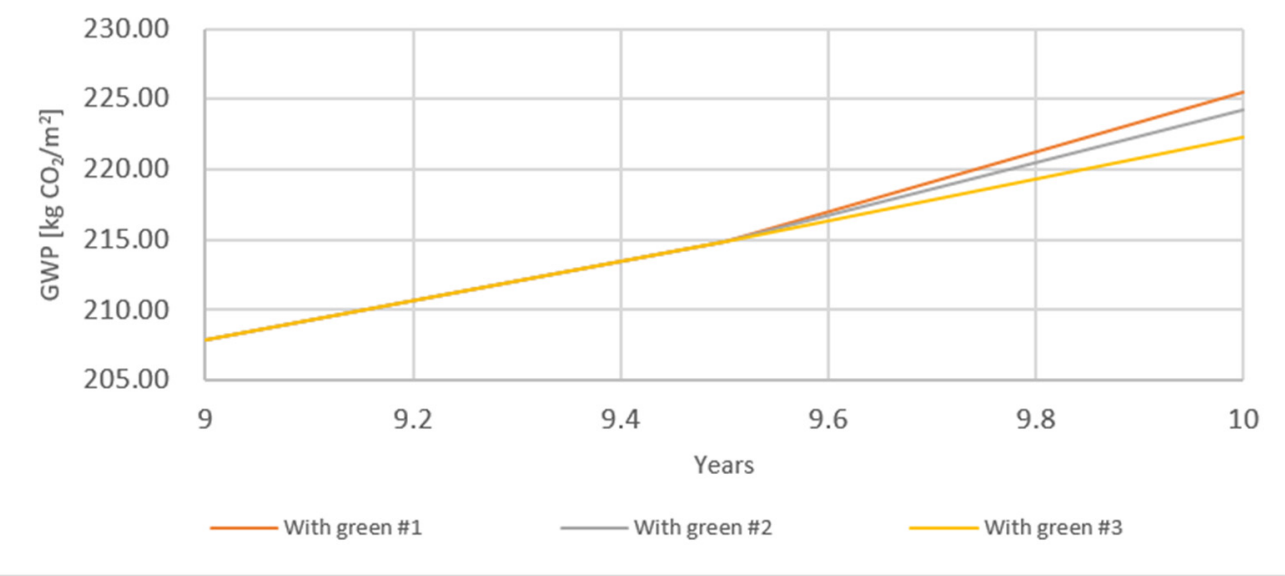

Figure 11. GWP trendlines throughout VGS lifetime (focus on Scenarios 1-3 at end of life).

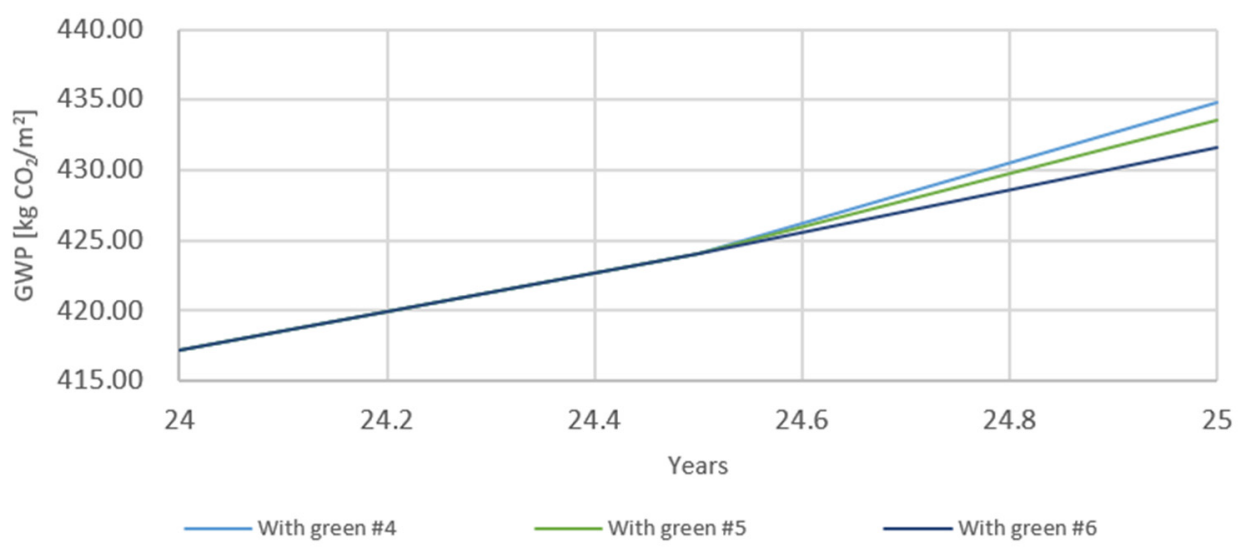

Figure 12. GWP trendlines throughout VGS lifetime (focus on Scenarios 4-6 at end of life). 
Author Contributions: Conceptualization, K.P. and F.M.; methodology, A.D.B. and A.G.; software, F.M. and L.M.; validation, M.G.; writing-original-draft preparation, K.P. and F.M.; writing-review and editing, L.M. and A.D.B.; supervision, M.G. and A.G. All authors read and agreed to the published version of the manuscript.

Funding: This research received no external funding.

Conflicts of Interest: The authors declare no conflict of interest.

\section{References}

1. Dover, J.W. Introduction to Urban Sustainability Issues. In Nature Based Strategies for Urban and Building Sustainability; Elsevier: Amsterdam, The Netherlands, 2018; pp. 3-15, ISBN 978-0-12-812150-4.

2. Frazer, L. Paving Paradise: The Peril of Impervious Surfaces. Environ. Health Perspect. 2005, 113, 113. [CrossRef] [PubMed]

3. European Commission. Directorate General for Research and Innovation. In Towards an EU Research and Innovation Policy Agenda for Nature-Based Solutions \& Re-Naturing Cities: Final Report of the Horizon 2020 Expert Group on 'Nature Based Solutions and Re Naturing Cities': (Full Version); Publications Office: Luxembourg, 2015.

4. Perini, K. Retrofitting with Vegetation Recent Building Heritage Applying a Design Tool—The Case Study of a School Building. Front. Arch. Res. 2013, 2, 267-277. [CrossRef]

5. Perez, G.; Perini, K. Nature Based Strategies for Urban. and Building Sustainability; Elsevier: Amsterdam, The Netherlands, 2018; ISBN 978-0-12-812324-9.

6. Ardente, F.; Beccali, M.; Cellura, M.; Mistretta, M. Building Energy Performance: A LCA Case Study of Kenaf-Fibres Insulation Board. Energy Build. 2008, 40, 1-10. [CrossRef]

7. Matos, C.; Teixeira, C.A.; Duarte, A.; Bentes, I. Domestic Water Uses: Characterization of Daily Cycles in the North Region of Portugal. Sci. Total Environ. 2013, 458, 444-450. [CrossRef] [PubMed]

8. Prasad, D.K.; Hall, M. The Construction Challenge: Sustainability in Developing Countries; Royal Institution of Chartered Surveyors (RICS): London, UK, 2005.

9. Thormark, C. A Low Energy Building in a Life Cycle-Its Embodied Energy, Energy Need for Operation and Recycling Potential. Build. Environ. 2002, 37, 429-435. [CrossRef]

10. Dunnett, N.; Kingsbury, N. Planting Green Roofs and Living Walls; Timber Press: Portland, OR, USA, 2008.

11. Köhler, M. Green Facades-A View Back and Some Visions. Urban Ecosyst. 2008, 11, 423-436. [CrossRef]

12. Manso, M.; Castro-Gomes, J. Green Wall Systems: A Review of Their Characteristics. Renew. Sustain. Energy Rev. 2015, 41, 863-871. [CrossRef]

13. Ottelé, M.; Perini, K.; Fraaij, A.; Haas, E.M.; Raiteri, R. Comparative Life Cycle Analysis for Green Façades and Living Wall Systems. Energy Build. 2011, 43, 3419-3429. [CrossRef]

14. Pérez-Urrestarazu, L.; Urrestarazu, M. Vertical Greening Systems. In Nature Based Strategies for Urban and Building Sustainability; Elsevier: Amsterdam, The Netherlands, 2018; pp. 55-63, ISBN 978-0-12-812150-4.

15. Ascione, F.; Bianco, N.; de' Rossi, F.; Turni, G.; Vanoli, G.P. Green Roofs in European Climates. Are Effective Solutions for the Energy Savings in Air-Conditioning? Appl. Energy 2013, 104, 845-859. [CrossRef]

16. Coma, J.; Pérez, G.; de Gracia, A.; Burés, S.; Urrestarazu, M.; Cabeza, L.F. Vertical Greenery Systems for Energy Savings in Buildings: A Comparative Study between Green Walls and Green Facades. Build. Environ. 2017, 111, 228-237. [CrossRef]

17. Perini, K.; Ottelé, M.; Giulini, S.; Magliocco, A.; Roccotiello, E. Quantification of Fine Dust Deposition on Different Plant Species in a Vertical Greening System. Ecol. Eng. 2017, 100, 268-276. [CrossRef]

18. Collins, R.; Schaafsma, M.; Hudson, M.D. The Value of Green Walls to Urban Biodiversity. Land Use Policy 2017, 64, 114-123. [CrossRef]

19. Dover, J.W. Green Infrastructure: Incorporating Plants and Enhancing Biodiversity in Buildings and Urban. Environments; Routledge: London, UK, 2015; ISBN 978-0-415-52124-6.

20. ISO UNI EN ISO 14040:2006. Environmental Management-Life Cycle Assessment-Principles and Framework; ISO: London, UK, 2021.

21. Magrassi, F.; Del Borghi, A.; Gallo, M.; Strazza, C.; Robba, M. Optimal Planning of Sustainable Buildings: Integration of Life Cycle Assessment and Optimization in a Decision Support System (DSS). Energies 2016, 9, 490. [CrossRef]

22. Manso, M.; Castro-Gomes, J.; Paulo, B.; Bentes, I.; Teixeira, C.A. Life Cycle Analysis of a New Modular Greening System. Sci. Total Environ. 2018, 627, 1146-1153. [CrossRef]

23. Pan, L.; Chu, L.M. Energy Saving Potential and Life Cycle Environmental Impacts of a Vertical Greenery System in Hong Kong: A Case Study. Build. Environ. 2016, 96, 293-300. [CrossRef]

24. Strazza, C.; Del Borghi, A.; Blengini, G.A.; Gallo, M. Definition of the Methodology for a Sector EPD (Environmental Product Declaration): Case Study of the Average Italian Cement. Int. J. Life Cycle Assess. 2010, 15, 540-548. [CrossRef]

25. Perini, K. Life Cycle Assessment of Vertical Greening Systems. In Nature Based Strategies for Urban and Building Sustainability; Elsevier: Amsterdam, The Netherlands, 2018; pp. 333-340, ISBN 978-0-12-812150-4.

26. Del Borghi, A.; Gaggero, P.L.; Gallo, M.; Strazza, C. Development of PCR for WWTP Based on a Case Study. Int. J. Life Cycle Assess. 2008, 13, 512-521. [CrossRef] 
27. Feng, H.; Hewage, K. Lifecycle Assessment of Living Walls: Air Purification and Energy Performance. J. Clean. Prod. 2014, 69, 91-99. [CrossRef]

28. Magliocco, A.; Perini, K.; Prampolini, R. Qualità Ambientale e Percezione Dei Sistemi Di Verde Verticale: Un Caso Studio. 2015. Available online: http://www.sitda.net/downloads/convegni_seminari/programma\%20sessioni\%20parallele_ABITARE\%20 INSIEME.pdf (accessed on 1 March 2021).

29. Perini, K.; Bazzocchi, F.; Croci, L.; Magliocco, A.; Cattaneo, E. The Use of Vertical Greening Systems to Reduce the Energy Demand for Air Conditioning. Field Monitoring in Mediterranean Climate. Energy Build. 2017, 143, 35-42. [CrossRef]

30. Rosasco, P.; Perini, K. Evaluating the Economic Sustainability of a Vertical Greening System: A Cost-Benefit Analysis of a Pilot Project in Mediterranean Area. Build. Environ. 2018, 142, 524-533. [CrossRef]

31. Magliocco, A.; Perini, K. The Perception of Green Integrated into Architecture: Installation of a Green Facade in Genoa, Italy. Aims Environ. Sci. 2015, 2, 899-909. [CrossRef]

32. Perini, K.; Magliocco, A.; Giulini, S. Vertical Greening Systems Evaporation Measurements: Does Plant Species Influence Cooling Performances? Int. J. Vent. 2017, 16, 152-160. [CrossRef]

33. ISO UNI EN ISO 14046:2016. Environmental Management-Water Footprint-Principles, Requirements and Guidelines; ISO: London, UK, 2016.

34. Edilclima. Available online: http:/ / en.edilclima.it/ (accessed on 1 March 2021).

35. EP Directive 2010/31/EU of the European Parliament and of the Council of 19 May 2010 on the Energy Performance of Buildings. 2010, pp. 13-35. Available online: http:/ / data.europa.eu/eli/dir/2010/31/oj (accessed on 1 March 2021).

36. ISPRA Rapporto Rifiuti Urbani 2020. Available online: https://www.isprambiente.gov.it/files2020/pubblicazioni/rapporti/ rapportorifiutiurbani_ed-2020_n-331-1.pdf (accessed on 1 March 2021).

37. Del Borghi, A.; Moreschi, L.; Gallo, M. Circular Economy Approach to Reduce Water-Energy-Food Nexus. Curr. Opin. Environ. Sci. Health 2020, 13, 23-28. [CrossRef]

38. Stocker, T.F.; Qin, D.; Plattner, G.-K.; Tignor, M.M.; Allen, S.K.; Boschung, J.; Nauels, A.; Xia, Y.; Bex, V.; Midgley, P.M. Climate Change 2013-The Physical Science Basis: Working Group I Contribution to the Fifth Assessment Report of the Intergovernmental Panel on Climate Change; Intergovernmental Panel on Climate Change, Ed.; Cambridge University Press: Cambridge, UK, 2014; ISBN 978-1-107-41532-4.

39. Huijbregts, M.A.J.; Rombouts, L.J.A.; Hellweg, S.; Frischknecht, R.; Hendriks, A.J.; van de Meent, D.; Ragas, A.M.J.; Reijnders, L.; Struijs, J. Is Cumulative Fossil Energy Demand a Useful Indicator for the Environmental Performance of Products? Environ. Sci. Technol. 2006, 40, 641-648. [CrossRef]

40. Boulay, A.-M.; Bare, J.; Benini, L.; Berger, M.; Lathuillière, M.J.; Manzardo, A.; Margni, M.; Motoshita, M.; Núñez, M.; Pastor, A.V.; et al. The WULCA Consensus Characterization Model for Water Scarcity Footprints: Assessing Impacts of Water Consumption Based on Available Water Remaining (AWARE). Int. J. Life Cycle Assess. 2018, 23, 368-378. [CrossRef]

41. CEN EN 15978:2011. Sustainability of Construction Works-Assessment of Environmental Performance of Buildings-Calculation Method; CEN: Brussels, Belgium, 2011.

42. Magrassi, F.; Rocco, E.; Barberis, S.; Gallo, M.; Del Borghi, A. Hybrid Solar Power System versus Photovoltaic Plant: A Comparative Analysis through a Life Cycle Approach. Renew. Energy 2019, 130, 290-304. [CrossRef]

43. Reverberi, A.; Del Borghi, A.; Dovì, V. Optimal Design of Cogeneration Systems in Industrial Plants Combined with District Heating/Cooling and Underground Thermal Energy Storage. Energies 2011, 4, 2151-2165. [CrossRef] 